レプラ 36,1

\title{
皮䖉冷凍移植法によるらい治療の試み
}

一免疫力移動法飞よるらいの治療飞ついて一II

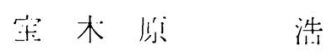

国立療荃所 栗生楽家園

（受付 1967作 4 月 7 日）

緒

言

拨に報告した疮例の効果に励まされて，遂次症例を增 し, 現在 5 症:例を得, 2 个月乃至 3 个月の覞察期間を過 ぎた今日何れも好影響を示して居り，晃投力移動法につ いて或程度の知見を织たつもりであり，報告して参考に 供すると共に御批判を仰ぐ次第である。

$$
\text { 術式 }
$$

契施方法は前回報告の通りであるが，今回はらいと搷 触長期に亘る健咏者の他に L 型 $\mathrm{q}$ 並に T 型 qでいづれも レ反応、ツ反応陽性の患省皮湑片を用いた。

症例

第一症例の坶移㥀を会めて各症例の経過等は次の如く である。

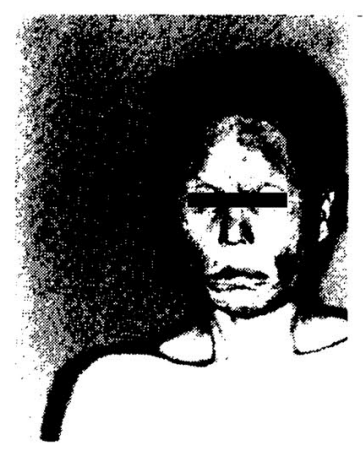

症例 1 治療前

桜门守 $\mathrm{L}_{3} \mathrm{pn}_{3}\left(\mathrm{~F}_{3} \mathrm{H}_{3} \mathrm{D}_{3}\right)$ 昭利116年癷病

$$
\text { 第一回 }
$$

栘 植 $\mu_{1}$ Non (接触30年:) $2 \times 3 \mathrm{~cm}$

冷涑洔間 70時間

移惝作打日 41. 12. 1
皮谄痁状17月目 顔面の浸潤，潮紅は明らか飞薄く

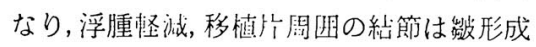

21 日目上半身の皮疹は吸収傾向下半身に变化なし

23日目 顔面の潮紅浮腫は归らかに去る

レプロミン反忍

10 日目 光田反灾 $\frac{4 \times 4}{6 \times 4(20 \times 17)}$ 不測

$\mathrm{Dh}$ 反応 $\frac{4 \times 4}{6 \times 5}$ 不測

21 日目

光田反成 $\frac{3 \times 3}{8 \times 7}-\frac{4 \times 4}{4 \times 4}$

$\mathrm{Dh}$ 反応 $\frac{5 \times 5}{5 \times 6(11 \times 11)} \frac{4 \times 4}{4} \frac{4}{\times 4}$

既往光田反応 $\frac{4 \times 5}{4 \times 5} \frac{4 \times 4}{4 \times 4}$

移模 1 . 5 着目 淡紅色健在

19日目 表支溥くとれあと等省

21日目表西小血简より小出向あり生々と健在

33日目 飴色の薄い餅状の瘀皮となり浮上する

乐; 挜

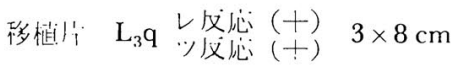

泠凍㭙間 72 時間

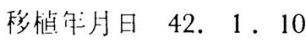

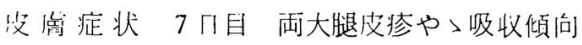

14П日移楠片の周辺結飾に趾を比成

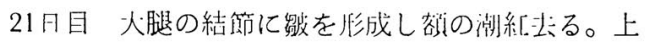
半身の度疹屯吸収傾们

34几日 皮疹は引続き褐任化，微版成

41 日目疼疹の吸収藷珂

100日目 効柴持続

レプロミン必迈 
Fig. 1-1 Before Treatment

T.K. 57, M., C-1, 2 days method

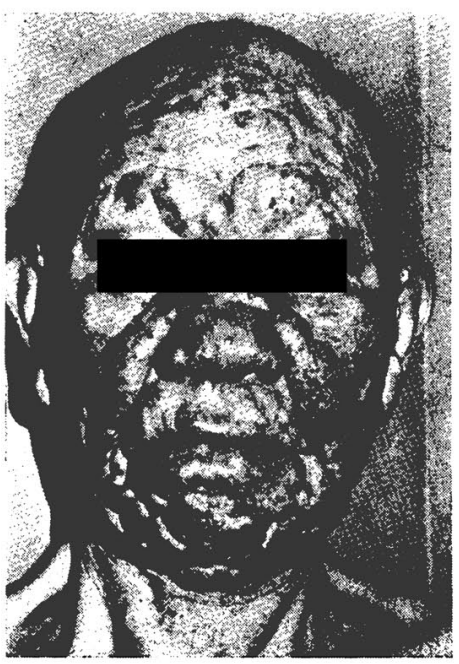

図 1-1 治療前

T.K. 男57歳（栗生）C-1 群，週 2 日法顔面全 面に, 高度のらい腫浸潤があり，所々結節を形 成している。結節の一部は自濽して, 潰煌を形 成している。左眼に角強膜らい腫がみられる。

Fig. 2-1 Before Treatment K.T. 30, M., A, 6 days method

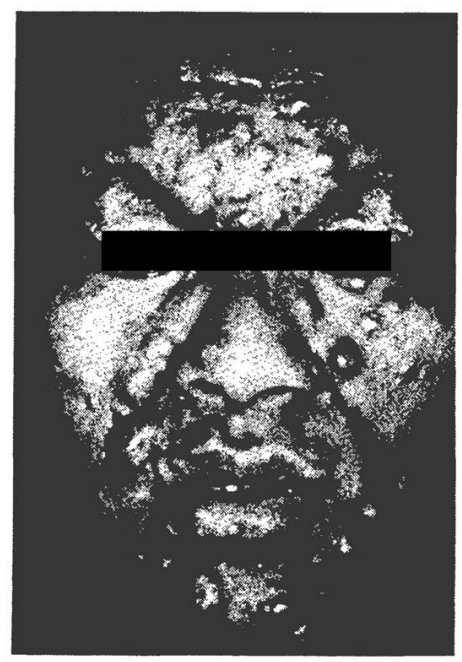

図 2-1 治療前

K.T. 男30歳（愛生）A 群, 週 6 日法顔面にビ マン性の浸潤がり，米粓大から蛋豆大の結節 がみとめられた。
Fig. 1-2 After 12 months

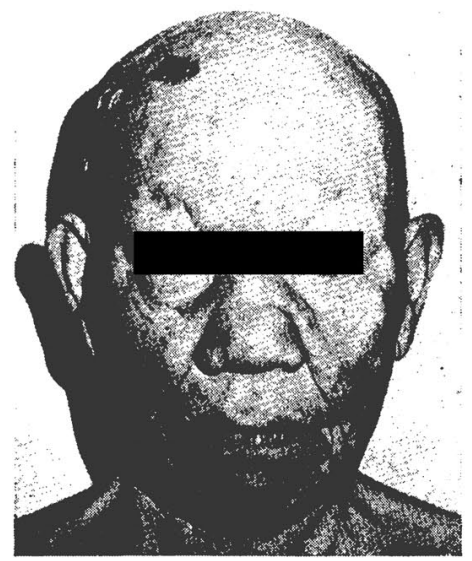

図 1-2 12力月後

浸洞と結節がよく吸収されている。潰煌は RFP 内服の数日後に治癔した。左眼の角強膜のらい 腫も,よく吸収されている。

Fig. 2-2 After 6 months

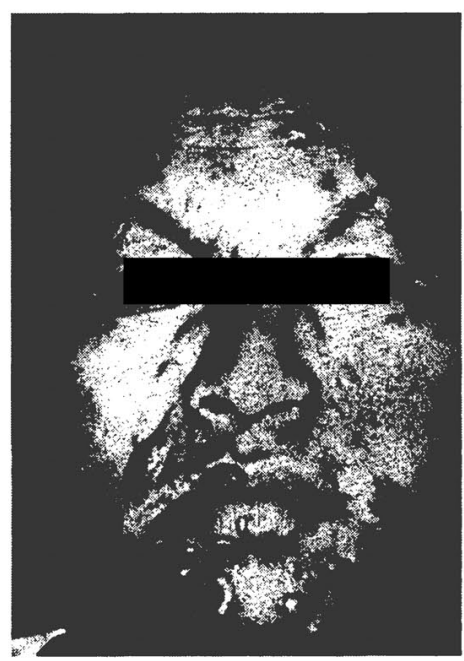

図 2-2 6 力月後

浸潤は吸収され，“ひきしまった”顔になった。 結節もやや小さく，硬くなって，黄色をおびる 傾向があらわれてきている。 
14日目

$$
\begin{aligned}
& \frac{5 \times 5}{10 \times 9} \frac{2 \times 2}{3 \times 4} \\
& \frac{4 \times 4}{6 \times 6}
\end{aligned}
$$

21日目

$$
\begin{aligned}
& \frac{5 \times 5}{5 \times 5} \frac{3 \times 3}{6 \times 5} \\
& \frac{5 \times 3}{8 \times 7}
\end{aligned}
$$

移植打 7 日目皮中出向, 紫色全体に淡紅色

14日目 黒く轅死を起し下半部のみ誗着

21日目黑色のま〉定学

34 月目 豩離

\section{症例 2}

\section{太○正○ $\mathrm{L}_{3} \mathrm{r}_{1} \mathrm{n}_{0}$ 炤和 29 仕発病}

移 植 片 Non (接触 38 年.) $2 \times 3 \mathrm{~cm}$

冷凍時間 72時間

移植作.月日 42 . 1 . 9

皮虞症状 14 几目両太腿前面の皮疹は色素沈着部以 外褪色化

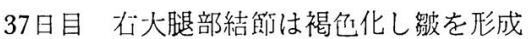

2 ケ月目 皮疹は乾燥し褐色化

レプロミン 反応

14 日目 光田反灾 $\frac{6 \times 6}{13 \times 25} \frac{4 \times 4}{12 \times 13}$

Dh 反応 $\frac{5 \times 6}{5 \times 6} \frac{5}{5} \times \frac{5}{5}$

21日目

光田反応 $\frac{2 \times 2}{4 \times 3} \frac{3 \times 3}{4 \times 5}$

Dh 反応 $\frac{4 \times 3}{6 \times 6}-\frac{3 \times 3}{4 \times 3}$

坏往光田反応 $\frac{3 \times 3}{5 \times 5}$

反応なし

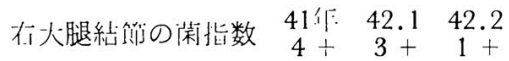

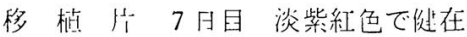

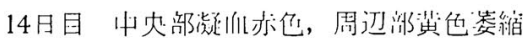

21日目 黄任部剝離し始む

28日目一部定皇

37 月目 剶離

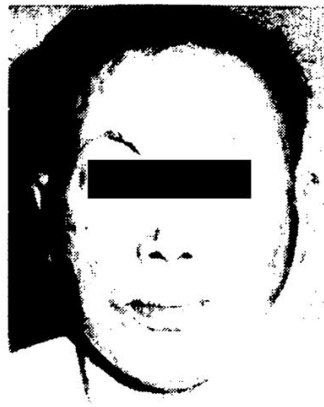

症例 3 治療前

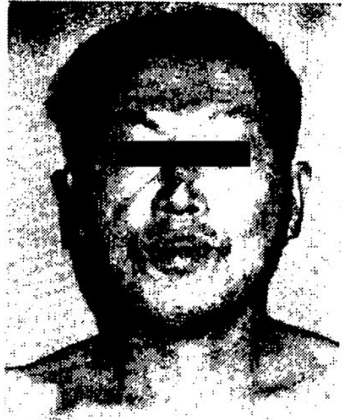

治療 2 力月
山○実 $\mathrm{L}_{3} \mathrm{r}_{1} \mathrm{n}_{2}\left(\mathrm{~F}_{2} \mathrm{H}_{2} \mathrm{D}_{0}\right)$ 昭和13年発病

移 植 片 Non（接嘞 35 年） $2 \times 3 \mathrm{~cm}$

冷涷時間 72時間

移植件月日 42.1 . 9

㳊笛症状 7 日目 顔面の腫倀消褪し始む

14日目 顔面の腫涱全く消ゆ

35日目 ENL かなり消褪し顔面の浮腫消褪, 皮疹 褪色化

2 ケ月目皮疹紴形成，褪色化 レプロミン反応

$$
\text { 14日目 } \begin{gathered}
\frac{4 \times 3}{4 \times 3} \frac{0}{3 \times 3} \\
\frac{0}{2 \times 1}
\end{gathered}
$$

21日目

$$
\begin{gathered}
\frac{0}{2 \times 2} \\
0 \\
\hline 4 \times 5
\end{gathered}
$$

反 忍 25日目 ENL 顔面腫脤，左股窩淋巴腺 腫脹疼痛

栘 植 7 日目 淡紅色能在

14日目中央部㠜们赤色, 周辺部黄色萎縮

21日目矩形のま〉定着

35日目一部定着, 矩形のま〉痂㥞のむの形成 39日目 剝離
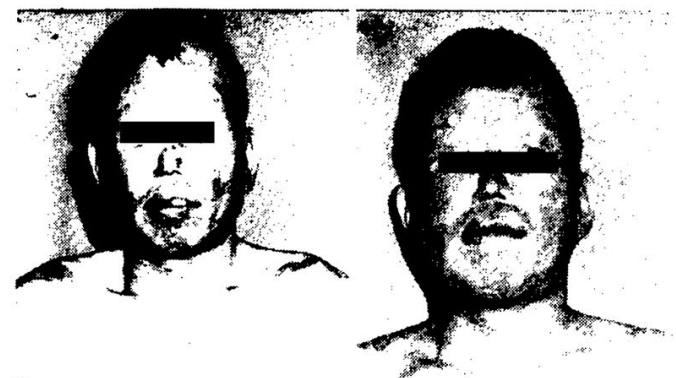

症例 4 治療前
治療 2 力月 


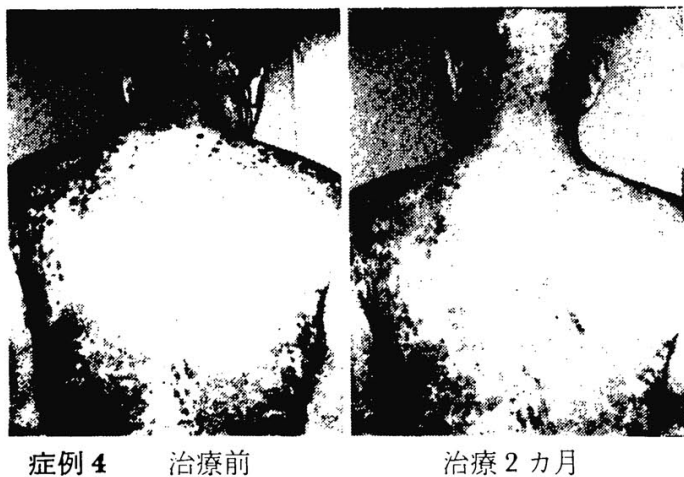

山○政 $\bigcirc \mathrm{L}_{3} \mathrm{Pn}_{2}\left(\mathrm{~F}_{2} \mathrm{H}_{2} \mathrm{D}_{0}\right)$ 昭和19年.発病

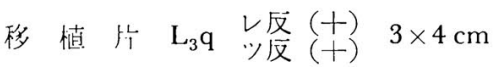

冷谏時間 72時間

移植細目 42. 1.9

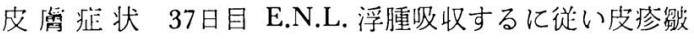
形成

49日目 ENL 浮腫消垁, 皮疹褐色消螁化, 紴形 成, 体调良好

2 个月目 E.N.L (一) 皮虞瀿形成, 褪色化 レプロミン反応

14日目 光田反応 $3 \times 3 \times \frac{3 \times 3}{3(9 \times} \times \overline{7)} \frac{0}{4} \times \frac{1}{4}$

21日目

$\mathrm{Dh}$ 反店

光田反心 $\frac{0}{1 \times 1}$

Dh 反応 $\frac{0}{4 \times 3}$

既往光田反心 $\frac{4 \times 4}{4 \times \frac{4}{4}}$

反 灾 3 日目 E.N.L. 浮腫出現

26日目 消褪し始む

移植片 7 日目 黄白他生気なし

14日目 褐䩿色定着

12日目 萎縮

28日目 剝離

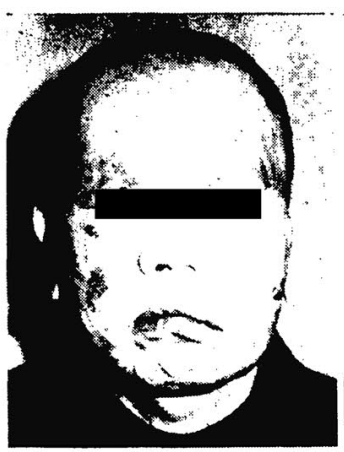

症例 5

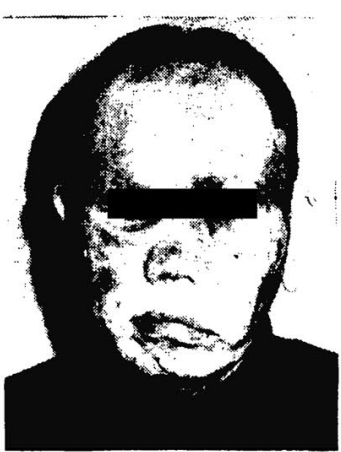

治療 2 力月
中○只 $\bigcirc \mathrm{L}_{3} \mathrm{pn}_{3}\left(\mathrm{~F}_{3} \mathrm{H}_{2} \mathrm{D}_{0}\right)$ 昭和14年発病

移㮩 $\mu_{7} \cdot \mathrm{TM}_{2} \mathrm{q}$ 㕅 $\left(\begin{array}{l}(+) \\ (+)\end{array} 2 \times 3 \mathrm{~cm}\right.$

冷谏時間 72 時間

移植尔月日 42.1212

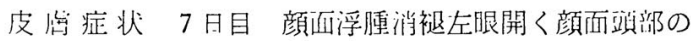
潮紅柽減

21日日 颜西頭部の潮紅中等度褪色萎縮, 绯形成, 他の皮落吸收倾向

23口目 所部の湖紅著明汇怪快す

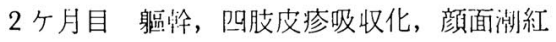
レプロミン反迈

$$
\begin{aligned}
& \text { 14日目 } \frac{5 \times 5}{7 \times 7} \frac{5 \times 4}{5 \times 4} \\
& 4 \frac{4}{4 \times 4} \quad 5 \times 4
\end{aligned}
$$

21 П目

$$
\begin{array}{cc}
\frac{6 \times 4}{6} \times \frac{4}{4} & \frac{0}{5 \times 4} \\
\overline{3} \frac{0}{3} \overline{3} & 0 \\
\frac{5 \times 2}{2 \times 2} & 3 \times 3 \\
\hline 5 \times 5 & \frac{3 \times 3}{4 \times 3}
\end{array}
$$

反

応 34 日目 䫓部再び潮紀

42 日目頭部潮紅.再吸収

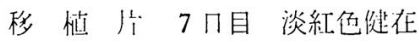

14几目 黑色化，周辺部黄色定管

21 日目一部残り殆んぞ䟝離

28 几目 剶離

成績

5 症例中 2 例に於て E.N.L の反岕期を見たが，他の 3 例之共に反応相消褪後いづれも皮疹の吸収傾后を見て おり,うち 1 例は既に祀憶にない吡に E.N.L.を経験した ものである。又全症例とも一時点においてレ反応の陽転 化傾问を示して扂り, 第 1 症例は 3 个月 9 日, 第 2 症例 以下は 2 个月の今日菌梲柰の成縜は以下の如くであり,

朋らかに菌の娍少を認めるものがあった。

移楒開始朔排菌数の高い简所顺に 3 -个所を撰び比較し た。数字はリドレー表による。

移忧後の勋離は28月から 39 月である。

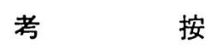

以上 5 症例 2 个月乃至 3 个月の経過を見るに各症例之 も明らかに波疹の吸収, 菌の減少を見, 且つレプロミン 


\begin{tabular}{c|c|c|c|c|c}
\hline \hline 症 例 & 1 & 2 & 3 & 4 & 5 \\
\hline 移植前 & $5+5+5+$ & $4+4+1+$ & $5+4+5+$ & $6+5+5+$ & $6+5+5+$ \\
現 在 & $4+4+4+$ & $3+2+(-)$ & $5+5+5+$ & $5+3+4+$ & $3+1+2+$ \\
\hline
\end{tabular}

反応の陽転化傾向にある。移植皮店片の長期定着は現在 は冷凍操作による移植拒絶反応の低下と考えているが, 免疫力の低下せる個体には移植拒絶反応の低下があると の説むある。乙の意味においてらい患者の免疫の低下も 考え, 上述の成績と併せ考えるとき，らいに抵抗を有す る者の免疫力が患者体内に移動し得たものと考えられ， 細胞免疫操作の一つとして新しい與味ある問題と思われ る。

\section{結論}

らいに抵抗を有すると思われる者の皮膚片 に冷凍操作を加え, 然る後らい患者の皮膚に 移植した結果，らいに対する免疫力をらい患 者の体内に移動せしめえたものと考えられ る。

移植皮膚片は 4 週から 5 週間位で剝離し永続性はない が，再三の移植により兟疫を賦与する方法はらいの化学 療法之相俟って難治らいの治療に多少とも有効である。

稿を終るにあたり，心よく皮虏片を提供された方々， 並に研究に協力下さった各位に改めて深甚の謝意を表す るものである。 